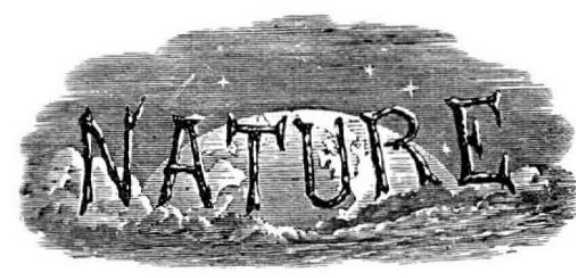

SATURDAY, APRIL 30, 1932

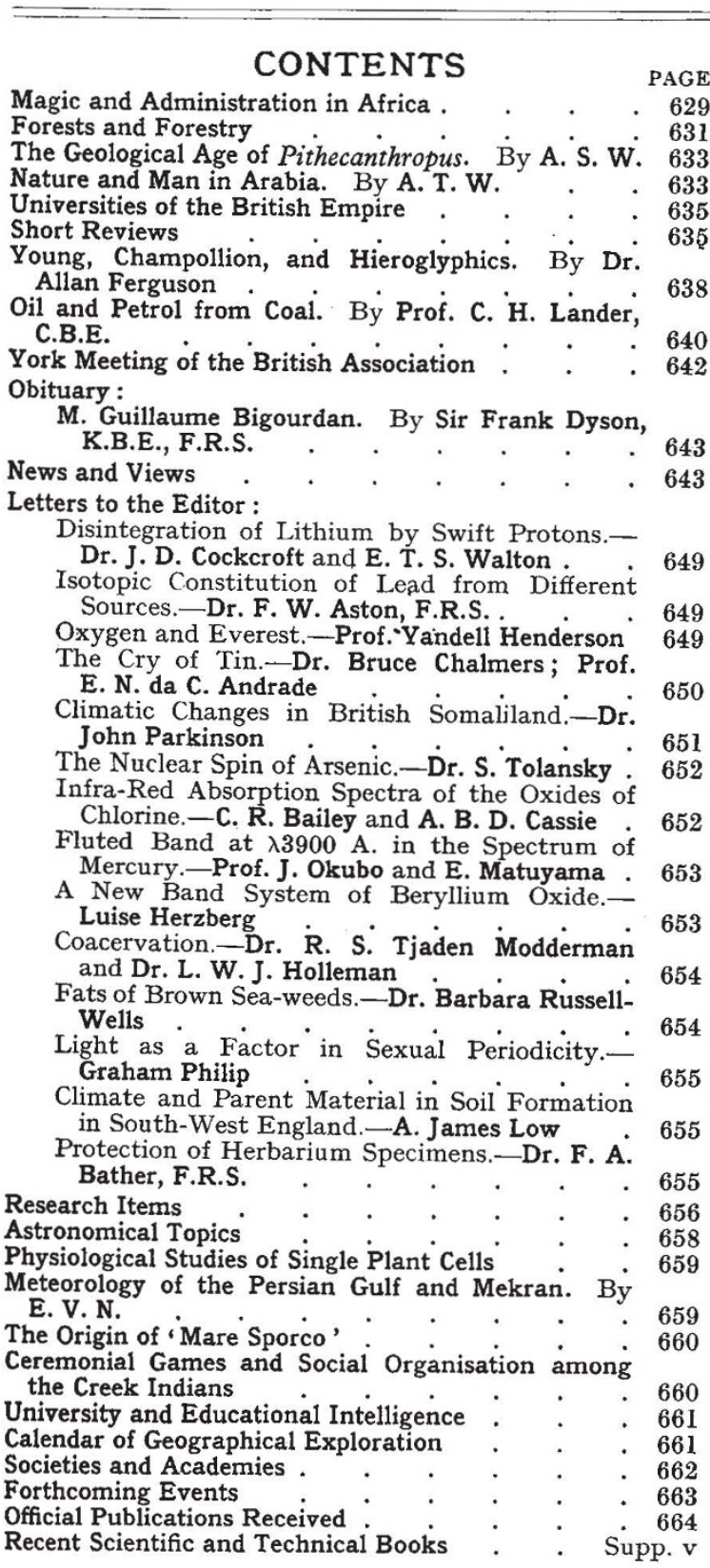

Editorial and Publishing Offices:

MACMILLAN \& CO. LTD.

ST. MARTIN'S STREET, LONDON, W.C. 2

No. 3261, VoL. 129]

\section{Magic and Administration in Africa}

T $T$ is inevitable that the anthropologist should suffer a feeling of disillusion, almost at times mounting to the level of discouragement, when he looks back on the history of our official relations with ' native' races during the period of, say, the last fifty years. The lessons of his science, in his eyes plain so that he who runs may read, have been neglected time and again. Racial prejudices and tribal customs and beliefs have been flouted. Sometimes they have been ignored through lack of knowledge, sometimes deliberately set aside or suppressed. Even where there has been little or no overt resistance, tribal organisation has been weakened, with a consequent deterioration in the character of the people; but often acceptance of the decree of the European administration has been enforced only by a heavy expenditure of blood and treasure, of which both sides have had to bear the cost.

In many instances much that has proved detrimental to the subject race and a source of innumerable difficulties, and even of danger, to their rulers might have been avoided had the administration been inspired by the sympathetic understanding which would have followed from a scientific knowledge of the social and religious pattern in the everyday lives of those they governed. Individual officers have not necessarily been to blame. Usually without any scientific training in the study of backward peoples, many of them acquired empirically an adequate knowledge of native institutions ; and at times, especially in India, their knowledge has probed deep into native ways of thought and action. Yet the whole trend of administration either attained no more than the preservation of Iaw and order without any specific idea of direction, or at best aimed at the amelioration of the conditions of the native in accordance with European ideals. Customs out of harmony with, or repugnant to, these ideals, such as cannibalism, human sacrifice, or head-hunting, were sternly suppressed without thought of their place or meaning in tribal life, even as missionary influence discouraged or forbade polygamy and the bride-price in Africa without heed or knowledge of the inevitable disintegration of the tribal, social and economic system which was bound to ensue.

When the anthropologist, in urging the application of the results of anthropological science in practical affairs, deplores the suppression of custom in certain instances, it must by no means be taken that he approves these practices or advocates their 
preservation, however interesting or vital they may be for the academic study of man and the development of his institutions. It is their suppression without due regard to their function in the social organisation that he deplores. Head-hunting, for example, among certain peoples of Papua or in the Naga Hills of Assam, was of vital significance in tribal life. Suppression would have broken economic, social, and religious bonds in the com. munity. A wise policy in administration, taking cognisance of the wide ramifications of the custom, retained the form of the institution, while securing the substitution of a pig or other animal for the human victim. A grasp of the essential function of the custom averted the disaster which would have followed its total suppression. The tribal organisation was saved from the danger of disintegration, and faith in the essential fair dealing of the administration was assured.

In Africa the problem of the attitude of the administration towards native custom is of the greatest moment on account of both the inherent difficulty of the question and the magnitude of the issues involved. A recent case of witchfinding in Kenya, to which reference is made in a well informed article by Frank H. Melland which appeared in the Times of April 13, and subsequent letters from Lord Lugard and others in later issues, serves to illustrate the difference in outlook between white and black which lies at the root of the difficulties of a European administration in dealing with the native. The Kenya case has attracted considerable attention owing to the number of defendants involved; but it is only one of many similar with which the authorities in different parts of Africa have had to deal within the last few years. In this latest case, a witch was beaten to death with staves by the members of the tribe, after she had been smelled out by the witchfinder. This action was in accordance with tribal custom; but as a result sixty persons were arrested, put on trial for murder, and condemned to death at Nairobi.

From the strict point of view of the law, the proceedings at Nairobi were in order, and the sentence awarded a penalty in accordance with the law. Witchfinding is forbidden by law, and the punish. ment of a witch by death as the outcome of a witchfinding ceremony is technically murder. From the point of view of the native, however, the law of the European administration is both illogical and unjust. The fact that in this and other cases the sentence has been remitted or commuted to a term of imprisonment is irrelevant. Nor is it of any avail to attempt to meet the native with the argument that the witchfinder is seeking something that does not exist. The majority of the natives of Africa hold firmly to the belief in the reality of magic. To them the evidence of innumerable happenings in everyday life bears out their assurance of its powers; and the deaths and other misfortunes of individuals are proof positive of the malevolent efficacy of the witeh.

It is, of course, common knowledge among those familiar with the African, that magic enters deeply into his life; but how this belief and its relation to witchfinding reacts in unexpected directions and incidentally affects the relations with Europeans may be illustrated further by the difficulties which arose in the South African mines some twenty-five to thirty years ago. One of the elements which contributed very largely to the shortage of native labour then experienced in the mines was the fear of the magic which, in native conception, was the cause of the high death-rate, and the prohibition by the authorities of the 'throwing the bones' by means of which the magician who had caused the deaths in individual cases, was smelled out. It was their belief that death was caused solely by magical agency; and even now no members of the Bathonga tribes who leave their country to work in the mines and elsewhere are readmitted without an elaborate purification ceremony to remove the evil magic which clings to them and might bring death and pestilence to other members of the tribe.

Witchfinding, however, is only one of the various means by which the native seeks to protect, not himself alone, but also the whole of his group from the influence of evil magic. To forbid witchfinding and to inflict the death penalty on those who mete out the customary retribution on the witch-in the eyes of the tribe a murderer and worse-is as irrational a proceeding in the eyes of the native as it would be Gilbertian in a civilised community if the detective who tracked down a criminal, and the court that inflicted punishment, thereby became liable to the extreme penalty of the law.

It might be thought that in course of time knowledge of the penalty inflicted by the law will have its effect and the employment of witchfinders die out. This is improbable, at least within a reasonable time, for more reasons than one. The example of what happened in England is instructive in this connexion. Even in the middle of the eighteenth century, a hundred years after the Essex witchfinder Hopkins had been discredited and long after witchcraft as such had ceased to be recognised in law, certain individuals caused the death of a suspected witch by the ducking test, and were convicted

No. 3261, VoL. 129] 
of murder. As both Lord Lugard and Mr. Melland point out, the situation in regard to witcheraft in Africa calls for an alteration in the law. Unless, moreover, the law recognises the African point of view, no measure is likely to provide a solution. However much it may be repugnant to European ideas, and whether magic be regarded as an illusion or not, the African's belief in magic must at least be accepted as a reality.

The acceptance of witchcraft and magic as something more than futile superstition which may be disregarded or swept aside goes deeper than a mere concession to the native's failure as yet to grasp the facts of existence as the European sees them. Nor should such beliefs be treated lightly if, as is conceivable, cases of suspected witcheraft were made the subject of inquiry, instead of being left, as they are now, as a matter purely of concern to the native, unless they result in some action which brings him within reach of the European's law. In present conditions, the only element in the witcheraft superstition of which the administration takes cog. nisance is the witchfinding and the execution of the witch-the very means whereby the native gives expression to the solidarity of the group, and tribal society acts in self-preservation against an anti-social force.

Tribal solidarity, and with it tribal discipline and the authority of the chief, are being assailed on many sides by the rapid changes now taking place in Africa. Since the War, the increased facilities for transport have made the native more mobile. He goes far afield to find employment and in increasing numbers. He earns money as an individual, whereas formerly his earnings were the property of his group. With this individual wealth at his disposal for furnishing the bride-price, no longer in many cases payable in cattle, he marries without reference to his family or tribal group, and often when he returns home he is a wealthier man than his chief.

What may be the effect in the modification of native institutions of these varied influences brought into play by the impact of white civilisation is now being made the subject of a much-needed inquiry by the International Institute of African Languages. The African is being hurried from his status of merely a component part in a unitary group, the family or tribe, into that of an individual independent of traditional ties, before he has had an opportunity of learning the responsibilities of the individual. Administrative action which in any way hastens this process prematurely may precipitate disaster.

No. 3261, VoL. 129]

\section{Forests and Forestry}

(1) An Outline of Forest Pathology. By Prof. Ernest E. Hubert. Pp. viii +543 . (New York : John Wiley and Sons, Inc. ; London : Chapman and Hall, Ltd., 1931.) 30s. net.

(2) Seeding and Planting in the Practice of Forestry: a Manual for the Guidance of Forestry Students, Foresters, Nurserymen, Forest Owners, and Farmers. By Prof. James W. Toumey. Second edition revised and enlarged by Prof. Clarence F. Korstian. Pp. xviii +507 . (New York: John Wiley and Sons, Inc.; London: Chapman and Hall, Ltd., 1931.) 25s. net.

(3) Histoire des bois et forêts de Belgique. Par le Comte Goblet d'Alviella. (Des origines à la fin $\mathrm{du}$ régime autrichien, Tome 4.) Pp. $448+23$ planches. (Paris: Paul Lechevalier; Bruxelles: Maurice Lamertin, 1930.)

(4) A Handbook of Coniferce: including Ginkgoacece. By W. Dallimore and A. Bruce Jackson. Second edition. Pp. xiv $+582+32$ plates. (London: Edward Arnold and Co., 1931.) 42s. net.

(5) Ökologie des Waldes: mit besonderer Berücksichtigung des deutschen Wirtschaftswaldes: ein Lehr- und Handbuch für Naturwissenschaftler. Von Prof. Dr. Alfred Dengler. Pp. vi $+272+2$ Tafeln. (Berlin: Julius Springer, 1930.) 25 gold marks.

(1) T THE author of this book requires no intro-

1 duction to those who have followed his work on the decay of timber. As may be expected in a book written by a professor of the University of Idaho, forest pathology is dealt with almost entirely from the point of view of North America, but as the causes of disease and decay, and the control measures necessary, are largely common to other regions, the book should be of interest to foresters generally.

The book is divided into three parts. Part 1 (introductory) contains a classification of tree diseases, and deals with the factors influencing disease, the relative importance of tree diseases, economic losses, and symptoms of disease and decay. Part 2, which bears the title "Forest Pathology", deals with various forms of injury, such as that caused by frost, drought, insolation, smoke, and other agencies, and describes certain specific diseases ; it concludes with a short account of control methods. Part 3, headed "Wood Pathology", deals with the decay of timber, both converted and unconverted.

The book has a practical outlook, and the fungi 